\author{
Mykoła Łesiuk \\ Przykarpacki Uniwersytet Narodowy \\ im. Wasyla Stefanyka, Iwano-Frankiwsk (Ukraina) \\ e-mail: mykolalesiuk@gmail.com \\ ORCID 0000-0001-5488-6626
}

\title{
GRAMATYCZNA KATEGORIA CZASU W JĘZYKU POLSKIM I UKRAIŃSKIM W UJECCIU DIACHRONICZNYM
}

Gramatyczna kategoria czasu we współczesnych językach słowiańskich została odziedziczona $z$ języka prasłowiańskiego, który charakteryzował się bardzo bogatym i skomplikowanym systemem form czasownika. Jest on, według Henryka Birnbauma [Бирнбаум 1987, 120-121], rezultatem głębokiej ewolucji systemu praindoeuropejskiego i może być uznany za innowacyjny w porównaniu $z$ praindoeuropejskim, zarówno na poziomie formalnym, jak i funkcjonalnym.

Złożoność systemu form czasowych języka prasłowiańskiego jest uwarunkowana przede wszystkim różnorodnością systemu czasu przeszłego, przyszłego i, oczywiście, teraźniejszego. Współczesne języki słowiańskie zachowały w zasadzie formy czasowe, które istniały w języku prasłowiańskim, jednak każdy $z$ nich kształtował i wykorzystywał ich zróżnicowanie według własnych zasad rozwoju językowego. Oczywiście, w ciagu ok. 1500 lat, które minęły od czasu rozpadu prasłowiańskiej wspólnoty językowej, zaszły w nich niejednokrotnie istotne zmiany dotyczace kategorii czasu. Żeby opisać te przemiany, konieczne jest ukazanie archetypów form prasłowiańskich oraz zestawienie ich $z$ formami odziedziczonymi $z$ języka praindoeuropejskiego.

\section{CZAS TERAŹNIEJSZY}

Rozpoczniemy nasz przegląd od form czasu teraźniejszego. W tych formach czasowniki tematyczne przybieraja pierwotne końcówki osobowe czasu teraźniejszego. Osobowe formy czasu teraźniejszego współczesnych języków słowiańskich, w zestawieniu $z$ odpowiednimi formami języków niesłowiańskich, pozwalają rekonstruować podstawy prasłowiańskie, a nawet praindoeuropejskie, a także końcówki osobowe. Według tematów podstaw czasu teraźniejszego czasowniki słowiańskie tradycyjnie dzieli się na pięć typów (klas) [Urbańczyk (red.) 1978, 42]. Pierwsze cztery typy maja określone podstawy tematyczne, w któ- 
rych przed końcówką jest przyrostek tematyczny, decydujący o przynależności danego czasownika do określonej klasy koniugacyjnej. Również na typy dzieli tematy podstaw czasowników w językach słowiańskich czasu teraźniejszego francuski slawista A. Meillet [Мейе 1951, 161-190].

Do pierwszego typu należały czasowniki $z$ tematem zakończonym na -o//-e: *neso//"nese (bezokol. *nesti), "vezo// *veze (bezokol. *vezti), peko//peke (bezokol. *pekti) i inne. Znany holenderski językoznawca, slawista Nikolas van Wijk, w swoim opracowaniu pt. Geschichte der altkirschenslavischen Sprache [Ван-Вейк 1957] poddał bardzo dokładnej i rzetelnej analizie pisane zabytki w języku staro-cerkiewno-słowiańskim. Przedstawia on pięć typów podstaw czasowników, lecz w pierwszym typie wydziela kilka podgrup czasowników: typ pierwszy a), do którego zalicza czasowniki bez wymiany samogłoskowej w rdzeniu (красти - крадж, решти - рекж); czasowniki, w których rdzeniu zachodzi wymiana samogłosek (чнстн - чьтж, тлҺштн - тиъкж) oraz czasowniki, których podstawa

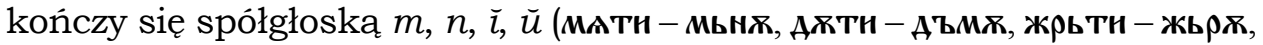
пнтн - пию пмоүтн - пловж). Do typu pierwszego b) należą czasowniki

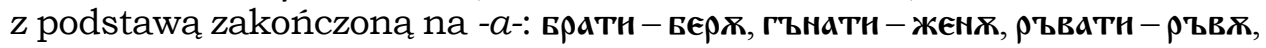
съсати - съсж itp. [Ван-Вейк 1957, 333-340].

Do drugiego typu należały czasowniki $z$ podstawą zakończona przyrostkiem tematycznym -no-//-nе-: Авигнжтн - двнгнж- Авнгнеши, мннжтн - мння - мннешн.

Czasowniki trzeciego typu miały podstawę zakończona przyrostkiem

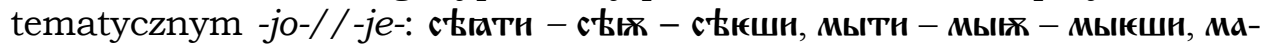
зати - маж及 - Мажеши, знати - знањж - знаеши.

Czwarty typ to czasowniki $z$ podstawa zakończona przyrostkiem te-

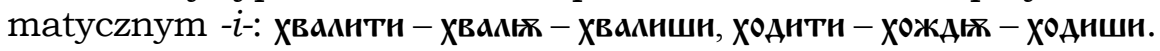

Piąty typ łączył tylko cztery czasowniki atematyczne, w których końcówki osobowe przyłączano bezpośrednio do podstawy zakończonej spółgłoska bez udziału przyrostka tematycznego. Do tej grupy należą czasowniki выти $\left({ }^{*}(j)\right.$ es-ti), дати ("dad-ti), -в всти ("věd-ti), фсти (*jěd-ti), a także czasownik нматн. W 1. os. lp. miały one końcówkę -мь $(<m i)$ ): ксмь, Аамь, вҺмь, Һмь, нмамь. We współczesnym języku ukraińskim czasownik мати (mieć) przybiera formy osobowe czasowników koniugacji I: маю, маш, ма, мамо, мате, мають. W języku polskim ma on formy koniugacji III: mam, masz, ma, mamy, macie, maja, dlatego nie zaliczamy go do grupy czasowników atematycznych.

Wymienione wyżej cztery typy czasowników tematycznych w języku polskim sa zgrupowane w cztery koniugacje, w ukraińskim - w dwie. Koniugacja I w języku polskim obejmuje czasowniki, które w 1. os. lp. mają końcówkę -ę, a w drugiej -esz. Poniżej przedstawiam cały współczesny paradygmat osobowy tych czasowników w języku polskim i ukraińskim oraz odpowiednie formy języków prasłowiańskiego i pra- 
indoeuropejskiego, od których bezpośrednio pochodza przedstawione formy współczesne.

\begin{tabular}{|c|c|c|c|c|}
\hline 1. & $\begin{array}{r}\text { pol. } \\
\text { pisz-e }\end{array}$ & $\begin{array}{r}\text { ukr. } \\
\text { nuw-y }\end{array}$ & $\begin{array}{c}\text { psł. } \\
\text { *pišo }\end{array}$ & $\begin{array}{c}\text { pie. } \\
\text { *pis-jo-am }\end{array}$ \\
\hline 2. & pisz-esz & nuu-eu & *piše-šb & ${ }^{*}$ pis-je-si \\
\hline 3. & pisz-e & nuw-e & *piše-tb & *pis-je-tĩ \\
\hline 1. & pisz-emy & пиш-емо & *piše-mb & *pis-je-mŏs \\
\hline 2. & pisz-ecie & nuw-eme & *piše-te & *pis-je-te \\
\hline 3. & pisz-Q & nuш-yms & *pišo-to & ${ }^{*}$ pis-jo-ntī \\
\hline
\end{tabular}

Jak widać, w powyższym zestawieniu poddano porównaniu i analizie czasownik typu III $z$ podstawa czasu teraźniejszego zakończoną na -jo//-je. Temat zakończony na -jo występuje zawsze w 1. os. lp. i 3. os. $1 \mathrm{~m}$. We wszystkich innych osobach występuje podstawa zakończona na -je.

Analizując współczesne formy osobowe czasowników w języku polskim, ukraińskim, a także w innych językach słowiańskich, możemy zrekonstruować zarówno prasłowiańskie, jak i wcześniejsze formy praindoeuropejskie. W 1. os. lp. w języku praindoeuropejskim występowała końcówka -am (albo -an). Zgodnie $z$ obowiąującym prawem głosowym w języku prasłowiańskim, według którego każda sylaba musiała być otwarta, takie połączenie głosek na końcu słowa zawsze przechodziło $\mathrm{w}-\mathrm{o}$ (o nosowe). Zanim to jednak nastapiło, jak możemy przypuścić, głoska tematu o łączyła się $z$ samogłoską końcówki $a$ i razem $z$ nosową spółgłoska $m(n)$ przechodziła w -o (o nosowe), które w językach: ukraińskim, białoruskim, rosyjskim, a w pewnych wypadkach również w czeskim i słowackim, przeszło $\mathrm{w} u$. Sytuacja analogiczna miała miejsce i w wypadku tworzenia form osobowych czasu teraźniejszego od czasowników pierwszego i drugiego typu, w których ostatnia samogłoska tematu o połączyła się $z$ pierwszą samogłoską końcówki i w ten sposób powstały formy z nosówką: *nes-o-am > *nes-o, *dvig-no-am > *dvign-o. Jednak język polski nie zachował historycznej końcówki 1. os. lp. -Q, dziś bowiem mamy końcówkę -ę. Jak pisze polski językoznawca Zenon Klemensiewicz, „końcówka 1. os. lp. *o ma polski odpowiednik -e, a więc kontynuację skróconej samogłoski nosowej prasłowiańskiej” [Klemensiewicz, Lehr-Spławiński, Urbańczyk 1981, 359].

Niełatwo jest zrozumieć proces, który miał miejsce w języku polskim. $\mathrm{W}$ 1. os. lp. -o (o nosowe) prasłowiańskie wszędzie konsekwentnie zmieniło się na $-e$ ( $e$ nosowe), natomiast w 3 . os. $1 \mathrm{~m}$. czasownika $z$ tematem zakończonym na -i (koniugacja II w języku polskim i ukraińskim) -ę zmieniło się na -o. Jak zaznacza Z. Klemensiewicz, w 3. os. lm. „uogólniła się polska końcówka -Q; jej stosunek do prasłowiańskich odpowiedników *-otb, *-ętb, w szczególności zanik jeru oraz poprzedzającej go 
spółgłoski - $t$, nie zostały dostatecznie wyjaśnione" [Klemensiewicz, Lehr-Spławiński, Urbańczyk 1981, 359-360]. ${ }^{1}$ Proces zaniku b (jeru) jest zrozumiały. Poddane redukcji jery (b i ъ) stały się zbędnymi fonemami w języku, straciły status fonemu. Gdy występowały w pozycji mocnej, wokalizowały się do $e, o$ (w języku polskim do e). Kwestię zaniku końcowego - $t$ omówimy w dalszej części artykułu. Osobowe formy czasowników czwartego typu (koniugacji II) powstały według następujących etapów:

1. *nos-i-am > *nosj-am > *noš- , scs ношљ, pol. noszę, ukr. нowý (noszú)

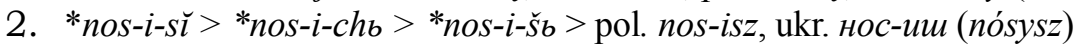

3. *nos-i-ť̆ $>*_{n o s i-t b}>$ pol. nosi, ukr. нócumb (nósyt')

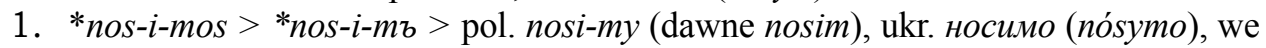
wschodnich gwarach, w poezji - носим (nósym)

2. *nos-i-te $>$ pol. nosi-cie, ukr. носи-me (nósyte)

3. *nos-i-nť̆> *nos-intb > *nos-ę-tb, scs носать, ukr. носять (nós'at'), pol. *nos- $i$ -

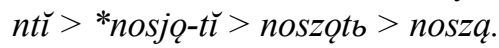

Warto wyjaśnić niektóre $z$ wyżej przedstawionych etapów. Tematyczna głoska -i- pod wpływem następującej po niej spółgłoski może być wymawiana jak $j$. Środkowojęzykowe miękkie $j$ zawsze wpływało na poprzedzająca je spółgłoskę, zmiękczając ją i wskutek palatalizacji powodujacc przejście do innej (miękkiej) spółgłoski. W naszym wypadku spółgłoska $s$ pod wpływem $j$ zmieniła się w 1 . os. lp. na š (sz). W jaki sposób powstało $\check{s}(s z)$ w 3. os. lm.? Można przypuścić, że przez analogię do formy 1. os. lp., przykładów podobnych procesów jest dużo. W języku ukraińskim właśnie przez analogię do formy 1 . os. lp. powstało $l$ epentetyczne w formach 3. os. lm. po spółgłosce wargowej: 1 . os. ${ }^{*} l u b-i-a n>* l u b j-a n>* l u b l-Q$ $>$ ukr. люблю́, pol. lubie, lecz 3. os. $1 \mathrm{~m}$. *lub-i-ntī > *lubę-tь > scs АюБать, ukr. люблять. W 3. os. $1 \mathrm{~m}$. nie było $j$. Pomimo że nie było warunków do powstania $l$ wstawnego, pojawiło się ono pod wpływem formy 1 . os. 1 p. Można jednak przyjąć inne wytłumaczenie.

Nosówka e z niewyjaśnionych do końca przyczyn zmieniła się na $Q .^{2}$ Tematyczna głoska -i- okazała się zbędna, o ile nosówka e, której była składowa, automatycznie zmieniła się na o. Następnie przed samogłoska $Q$ zakończenie tematu $-i$ - zmienia się na $j$, które oddziałuje na $s$ i zmienia je w š. Tak mogła powstać współczesna polska forma noszą.

W języku ukraińskim wszystkie czasowniki, jak wspomniano wyżej, zgrupowane sa w dwie koniugacje. Pierwsza koniugacja to czasowniki pierwszych trzech typów (tematy zakończone na -o//-e, -no//-ne, -jo//-je),

1 Trzeba uwzględnić tu fakt, że w 1. os. lp. wygłosowe - $Q$ było samogłoska krótka, która w późniejszej ewolucji samogłosek nosowych w języku staropolskim przechodziła w -e. Taka sytuacja nie zachodziła w formach 3. os. 1m. Przypis red.

2 Jw. 
a druga to czwarty typ (temat zakończony na - $i$-). W pierwszej koniugacji czasowniki w 3. os. $1 \mathrm{~m}$. mają końcówki -ymb, -юmь $\left(<*(j)\right.$ otb $<{ }^{*}$ o-ntì), $\mathrm{w}$ drugiej - -amb, -яmь $\left(<{ }^{*}(j) e ̨ t ı<{ }^{*} i-n t i\right) . \mathrm{W}$ języku polskim według tradycyjnej klasyfikacji czasowniki sa zgrupowane w cztery koniugacje: I, -e, -esz (pisze, piszesz); II, -e, -isz (robie, robisz); III, -am, -asz (czytam, czytasz); IV, -em, -esz (umiem, umiesz).

Pierwsze dwie koniugacje w 1 . os. $1 \mathrm{~m}$. mają końcówkę -ę, lecz różnią się swoimi końcówkami w 2. os. lp. Czasowniki koniugacji I maja końcówkę -esz, a koniugacji II - -isz (-ysz) (zob. przykłady powyżej).

Trzecia polska koniugacja to w zasadzie czasowniki trzeciego typu, w których temat -jo-//-je- dołącza się do głoski (przeważnie a). Pokażemy historie tych form:

1. *kocha-jo-am > *kocha-jo > ses көхањ, ukr. кохаю, pol. kocha-m

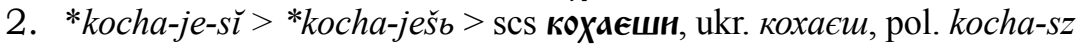

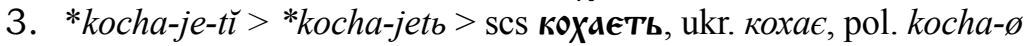

1. *kocha-je-mos > *kocha-jeтъ > scs кохаємz, ukr. кохаємо (кохаєм), pol. kocha-my

2. *kocha-je-te $>$ *kocha-jete $>$ scs кохаєтє, ukr. koxaєme, pol. kocha-cie

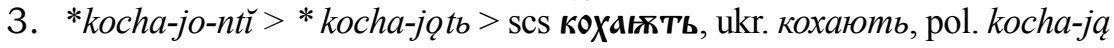

Jeśli porównać formy osobowe czasowników w językach: polskim, ukraińskim, rosyjskim (który faktycznie zachował formy staro-cerkiewnosłowiańskie), czeskim i słowackim, to zobaczymy dużo podobieństw. Wspólna cecha jest, na przykład, utrata końcowego -t w 3. os. lp. i lm. O ile jednak w języku polskim, czeskim i słowackim końcowe -t zanikło w 3. os. zarówno w liczbie pojedynczej, jak i w liczbie mnogiej, o tyle w języku ukraińskim ten proces zaniku jest jeszcze żywy, czyli niezakończony. Ostatecznie końcowe -to zanikło wyłącznie w koniugacji I (pierwsze trzy typy czasowników) tylko w liczbie pojedynczej: on (ona, ono) несе, везе, пише, двигне, їде (transl. nese, weze, pysze, dwyhne, jide) itp. Jednak w 3. os. $1 \mathrm{~m}$. w tych czasownikach końcowe -to konsekwentnie pozostało: несуть, везуть, пишуть, читають, двигнуть, їуть (transl. nesut', wezut', pyszut', czytajut', dwyhnut', jidut').

W koniugacji II ukraińskiej (czwarty typ grupy tematycznej) końcowe -to występuje w formach obu liczb: ходить, носить, сидить-ходять, носять, сидять (transl. chodyt', nosyt', sydyt'-chod'at', nos'at', sydat'). Końcowe (stwardniałe) -t zachowało się we wszystkich czasownikach w języku rosyjskim i białoruskim w 3. os. obu liczb (носит-носят, ходит-ходят; transl. nosit - nos'at, chodit - chod'at).

Całkiem inna sytuacja ma miejsce w gwarach języka ukraińskiego. W koniugacji I, podobnie jak w języku literackim, w 3. os. lp. końcowe -tb zanikło. W liczbie mnogiej nastapiło stwardnienie spółgłoski -t (несym, numym, transl. nesut, pyszut). Natomiast w koniugacji II w gwarze pokuckiej, bojkowskiej i huculskiej -t czy -to zanikło, podobnie jak w języku polskim.

Prasłowiańska nosówka e, jak wiadomo, w języku ukraińskim zmieniła się na -'a, lecz w gwarach zachodnich języka ukraińskiego w syla- 
bie akcentowanej - na e denazalizowane $z$ pochyleniem do $u\left(e^{u}\right)$ : cud'é $e^{u}$, хот 'éu , фал 'éu (forma literacka сидять, хвалять, хочуть (<хотять), pol. sie$d z a$, chca, chwala. W pozycji nieakcentowanej byłe $e \mathrm{w}$ gwarze pokuckiej przechodzi w i: xódi, нóci, л’ýбji (pol. chodza, nosza, lubia). W gwarze naddniestrowskiej i bojkowskiej możliwe jest występowanie na końcu twardego -t: xódim, нócim, л'ýбjim. W gwarze podolskiej wymawia się 'a tak samo jak w języku standardowym, lecz bez końcowego - $t$ czy -tb: xód'a, нóc'a, л'ýбja. Na Naddniestrzu, Bojkowszczyźnie spotyka się formy zredukowane (nieregularnie) końcowego -t również i w 3. os. lp. (można przypuścić, że zjawisko to zachodzi pod wpływem form analogicznych czasowników koniugacji pierwszej): póбu, xódu, нócu. Dlatego uważa się proces zaniku końcowego -t, -tъ za żywy. W wypadku języków zachodniosłowiańskich mamy do czynienia $z$ zanikiem, w innych bywa różnie. Jaka jest przyczyna zniknięcia końcowego -t? Po zaniku jerów w późnym języku prasłowiańskim często zachodzą zmiany na końcu wyrazów i sylab: stwardnienie wargowych spółgłosek, stwardnienia albo inne zmiany (na przykład, w języku polskim sonant $r$ : *lěkarı > ukr. лiкаp, pol. lekarz; ${ }^{*}$ golobb > ukr. голуб, pol. gołab); zanik spółgłosek $\left({ }^{*} a z^{*}\right.$ b, ${ }^{*}$ jaz' $>$ > ja) i in. Możliwe, że również końcowe - $t \mathrm{w}$ formach czasowników wymawiane było niewyraźnie i z czasem w poszczególnych dialektach języka prasłowiańskiego stwardniało albo znikło.

Druga ważna zmiana, która różni język polski od ukraińskiego, to wypadanie tak zwanego interwokalicznego $j$ i kontrakcja samogłosek. To zjawisko jest charakterystyczne dla różnych języków słowiańskich, lecz $\mathrm{w}$ każdym $\mathrm{z}$ języków przejawia się nieco inaczej.

Rozpatrzymy przykłady. We wszystkich formach osobowych, oprócz 1. os. lp. i 3. os. lm. przyrostek tematyczny -je- przyłącza się do głoski rdzenia a: *kocha-je-šı, *kocha-je-to itp. Spółgłoska $j$ wypada, powstaje połączenie dwóch samogłosek - $a$ i e. Między nimi zachodzi asymilacja postępowa, $a$ wpływa na $e$, upodabniając je do siebie. Powstaje grupa $a a$, która przechodzi w rezultacie ściagnięcia w długie $\bar{a}$, potem w zwyczajne $a$. W wyniku tych procesów utworzyły się ściagnięte formy *kocha-je-šb > *kochaešb > *kochaašb, *kochāšb > kochasz (kocha, kochamy, kochacie). W potocznym języku ukraińskim również jest możliwa podobna kontrakcja w różnych formach, a we wschodnich dialektach zachodzi ona w szczególności w 3. os. lp. podobnych czasowników: кoxá, uumá, знá (pol. kocha, czyta, zna).

Co prawda, również w języku polskim jest grupa czasowników, $\mathrm{w}$ których tradycyjnie zachował się temat $-j e$. W niektórych formach do kontrakcji nie doszło. To czasowniki typu sinieje, czernieje, bieleje; w zabytkach historycznych można zobaczyć formy umieję, umiejesz, umieje, właśnie taki paradygmat osobowy miały też czasowniki śmieć, rozumieć, lecz później w formach 1 . os. lp. tych czasowników pojawiła się pod wpływem innych czasowników tej koniugacji końcówka e. O tym, że kontrakcja to $\mathrm{w}$ językach słowiańskich, $\mathrm{w}$ tym $\mathrm{w}$ języku polskim, zjawisko 
współczesne, świadczą użycia staropolskich czasowników podnaszaję, wylewaje, śćwirdzaje, powiadaje. Podobne formy rejestrujemy w zabytkach polskich XIV-XV w. [Klemensiewicz, Lehr-Spławiński, Urbańczyk 1981, 361].

W wyniku kontrakcji takich form powstała końcówka -(a)m w 1. os. lp. III polskiej koniugacji. Końcówka -mĩ w 1. os. lp. powstała pod wpływem czasowników atematycznych.

Czasowniki atematyczne, jak już zaznaczono, nie miały przyrostka tematycznego i końcówki dołączano do podstawy zakończonej na spółgłoskę. W języku prasłowiańskim do tej grupy czasowników należały: *dadti, *wẽdti, *jědti, *jesti (*byti). W odróżnieniu od czasowników tematycznych w 1 . os. lp. miały one końcówkę -mĭ, a nie -am(n). Właśnie czasowniki $z$ tą końcówka $(-m i)$ dały druga podstawę w języku polskim do czasowników III koniugacji czasowników, zakończonych w 1. os. lp. na -am oraz koniugacji IV, mającej w 1. os. lm. końcówkę -em. Poniżej przedstawiono rozwój form osobowych atematycznych czasowników.

1. os. 1p.

$* d a d-m \check{\imath}>* d a-d m b>d a-m b>$ pol. dam, ukr. daм (transl. dam)

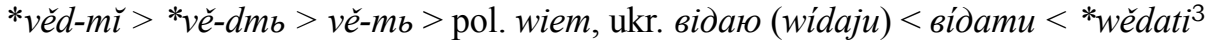

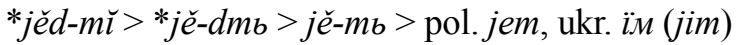

$*$ jes-m $\breve{\imath}>$ *jes-mb $>$ pol. jeśm $>$ jestem, stukr. $\epsilon c M b$, ukr. $\epsilon$ (je)

2. os. $1 \mathrm{p}$.

*dad-si $>* d a-d s i>d a-s i>$ ukr. dacu (dasý), pol. dasz

*vĕd-si $>$ *vě-dsi $>$ vě-si $>$ pol. wiesz, ukr. вidacm (wídajesz) $<$ вídamu $<*_{\text {wědati }}$

*jĕd-si $>$ *jě-dsi $>$ jě-si $>$ ukr. ïu (jisý), pol. jesz

*jes-si > *je-ssi > je-si > stpol. jeś > pol. jesteś, stukr. $\epsilon c u ́(j e s i)$, ukr. $\epsilon$ (je)

3. os. $1 \mathrm{p}$.

$* d a d-t \grave{l}>* d a-d t \breve{l}>d a-s t b>$ ukr. dacmb (dast'), pol. da

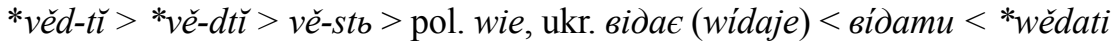

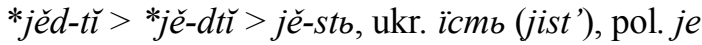

*jes-ťl > *je-stb > pol. jest (rzadko jeść), stukr. $\epsilon c m b$ (jest'), ukr. $\epsilon$ (je)

1. os. $1 \mathrm{~m}$.

*dad-mŏs $>* d a-d m ъ>d a m s>$ pol. damy, ukr. daмó (damó)

*věd-mŏs $>*$ *ě-dmъ $>$ pol. wiemy, ukr. вìаємo (wídajemo $)<$ вídamu $<*$ wědati

*jěd-mŏs $>$ *jě-dmъ > pol. jemy, ukr. üмó (jimó)

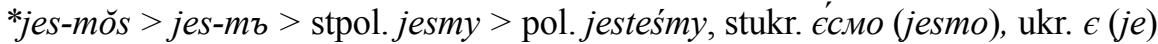

${ }^{3} \mathrm{~W}$ języku ukraińskim czasownika *vědti > *věsti używa się tylko w formie przedrostkowej w aspekcie dokonanym - відповісти, розповісти ('odpowiedzieć, 'opowiedzieć'), я відповім, ти розповіси, він розповість itd. ('ja odpowiem', 'ty rozpowiesz', 'on rozpowie'). Więc paradygmat tego czasownika wyglądałby tak: -вім, -віси, -вість, -вімо, -вісте, -відять. Zamiast tych form sa używane formy (patrz wyżej) utworzone od wspólnordzennego *vědati w znaczeniu wiedzieć (ukr. знamu - transl. znaty). 
2. os. $1 \mathrm{~m}$.

$*$ dad-te $>*$ da-dte $>*$ da-ste $>$ pol. daście $>$ dacie, ukr. dacmé (dasté)

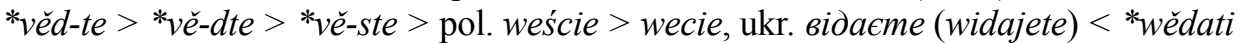

*jĕd-te $>$ *jě-dte $>$ *jě-ste $>$ pol. jeście $>$ jecie, ukr. ïcmé (jisté)

*jes-te > *je-ste > je-ście > pol. jesteście, stukr. $\epsilon$ cme (jeste), ukr. $\epsilon$ (je)

3. os. $1 \mathrm{~m}$.

*dad-ntı $>* d a-d n t \check{\imath}>$ dadęntb $>$ pol. (niepraw.) dadza, ukr. (niepraw.) dadymb (dadut')

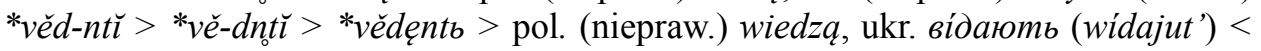
*wědati

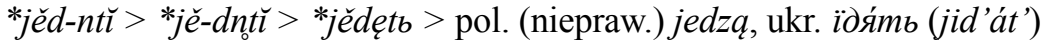

*(je)so-ntĭ $>*_{\text {son-tb }}>$ sqtb $>$ pol. sa, stukr. cymb (sut'), ukr. $\epsilon$ (je).

Jak widać w powyższym zestawieniu, w 1 . os. 1p. i lm. we wszystkich tych czasownikach mamy uproszczenie grupy spółgłoskowej - $d m$ (dadmı, dadmı > dam). W obu językach w 1. os. lp. zaszło stwardnienie wargowego końcowego -m. W 2. os. 1p. upraszcza się grupa -ds-, a w czasowniku *jesti (byti) odbywa się kontrakcja dwóch -ss- ( $\left.{ }^{*} j e s-s i>j e-s i\right)$. $\mathrm{W}$ języku polskim odbywa się redukcja końcowego $-i(-s i>-s)$. W języku ukraińskim zachowuje się praindoeuropejskie zakończenie -si (-cu). Nawiasem mówiąc, język ukraiński jako jedyny ze wszystkich języków słowiańskich zachował tę dawną końcówkę w pierwotnej postaci, co prawda, tylko w czasownikach atematycznych. W czasownikach tematycznych (najpierw w czasownikach $z$ podstawa na $-\imath$ ) spółgłoska $s$ po głosce $i$ (a później i po innych) przed następna głoska przeszła w ch, a potem w š.

W 3. os. pl. i 2. os. $1 \mathrm{~m}$. zaszła dysymilacja $d t>s t\left({ }^{*} d a-d t i ̄>d a-s t b,{ }^{*} d a-\right.$ $d t e>d a-s t e)$. Jednak w języku polskim oczekiwane zakończenie formy -st znika pomimo braku warunków fonetycznych i pozostaje tylko forma da-ø. Można przypuścić, że ta forma powstała przez analogię do form 3. os. 1p. czasowników tematycznych, w szczególności czasowników koniugacji III (on czyta, pyta, kocha, zna itp., a więc - da. W 2. os. lm. końcówka -te zmienia się na -cie, miękka spółgłoska ś łączy się $z$ następną ć i w wyniku mamy -cie-dacie.

Na szczególna uwagę zasługuje czasownik być, który w języku ukraińskim zupełnie stracił formy czasu teraźniejszego. W języku potocznym na zachodniej Ukrainie jego pozostałości są często używane (nрочumaла-м иікаву книжку, ходили-смо на прогулянку - pol. przeczytałam ciekawa ksiażkę, chodziliśmy na spacer). W języku standardowym moga być wykorzystywane tylko w celu stylizacji jako archaizmy.

Język polski, w odróżnieniu od innych języków słowiańskich (czeskiego, słowackiego, bułgarskiego), nie zachował form osobowych tego czasownika w postaci, której moglibyśmy się spodziewać jeśm, jeś, jeśmy, jeście), natomiast już w XV w. powstały nowe formy z zachowaniem form szczątkowych -m, -ś, -śmy, -ście (przed końcówka pojawia się wstawne e i powstaja odpowiednio końcówki -em, -eś, -eśmy, -eście), 
które dołączono do formy 3. os. 1p. podstawy jest: jest-em, jest-eś, jest-eśmy, jest-eście na wzór form czasu przeszłego tego czasownika rodzaju męskiego byt-em, byt-eś [Klemensiewicz, Lehr-Spławiński, Urbańczyk 1981, 374]. Zmieniła się również forma 3. os. $1 \mathrm{~m}$. * sǫtb na sa. Tutaj po zaniku jeru zniknęło również końcowe $t^{\prime}$, jak to się stało w czasownikach tematycznych i w czasowniku atematycznym *dadti - da (<dast).

\section{CZAS PRZYSZEY}

Specjalne formy osobowe czasu przyszłego miał tylko czasownik być $\left({ }^{*} b y t i\right)$. Sa one utworzone od rdzenia *by-, który pochodzi od praindoeuropejskiego *bhū-. Można przypuszczać, że podstawą w tym czasowniku była forma *bhūnd-, która przeszła w bod- $(\bar{u} n>q)$ analogicznie do zmian w rdzeniu czasowników atematycznych (dad-, wěd-, jed-), co potwierdzają właśnie te formy osobowe w języku staro-cerkiewno-słowiańskim, polskim, a zatem również w prasłowiańskim:

\begin{tabular}{|c|c|c|c|}
\hline psł. & $\operatorname{scs}$ & pol. & ukr. \\
\hline$b o d-q$ & $б \varrho \partial-Q$ & będ-e & $б y \partial-y$ \\
\hline$b q d-e-\check{s} \check{l}$ & боде-ии & będzi-esz & буд-еши \\
\hline$b q d-e-t b$ & бфде-ть & będzi-e & буд-е \\
\hline bod-e-mb & бфде-мъ & będzi-emy & буд-емо \\
\hline bod-e-te & боде-те & będzi-ecie & буд-ете \\
\hline bod-otb & бфд-фтьь & $b e ̨ d-a$ & буд-уть \\
\hline
\end{tabular}

Inne czasowniki wyrażały czas przyszły w trzech różnych formach. Czas przyszły dokonany (prosty) zarówno w języku polskim, jak i w języku ukraińskim wyrażano formami czasu teraźniejszego czasownika dokonanego: *začıno, "napišo itp. Oprócz tego były jeszcze dwie formy złożone. Czas przyszły pierwszy futurum primum był wyrażany połączeniem bezokolicznika $z$ formami czasu teraźniejszego czasowników imèti, načęti, chotěti, byti (načno nesti, bodo nesti, nesti imo) [Мемьничук 1966, 316]. Czas przyszły złożony drugi futurum exactum miał postać połaczenia form czasownika być czasu przyszłego $z$ imiesłowem czynnym czasu przeszłego na -lъ: będę pisał, będziesz pisał itd. W języku polskim tej formy używa się od czasów najdawniejszych [Klemensiewicz, Lehr-Spławiński, Urbańczyk 1981, 374] do dziś.

W języku ukraińskim tej formy używa się tylko w niektórych gwarach (obwód lwowski i tarnopolski), w języku standardowym i w potocznym występuje również $\mathrm{w}$ innych regionach $\mathrm{w}$ dwóch postaciach. Pierwsza to forma złożona $z$ bezokolicznika danego czasownika $z$ formami osobowymi czasu teraźniejszego czasownika posiłkowego być (буду нести, будеш писати), podobnie jak w języku polskim. Druga to forma syntetyczna, 
utworzona w wyniku połaczenia bezokolicznika danego czasownika $z$ formami osobowymi czasu teraźniejszego czasownika (w postpozycji) *imati: pisati imo > писати-иму > писатиму, писатимеш, писатиме, писатимемо, писатимете, писатимуть. Jak widać, w tym wypadku zaszła kontrakcja dwóch samogłosek ii w jedną i dwa czasowniki połaczyły się w jeden wyraz. Co prawda, w języku potocznym, w szczególności w regionach zachodnich, ta forma nie jest powszechna. Występuje natomiast w gwarze pokuckiej, huculskiej w formie analitycznej z czasownikiem imati w pozycji przed danym czasownikiem: ти меш писати, він ме писати, ми мемо писати, ви мете писати. Mamy zatem w języku ukraińskim następujące formy czasu przyszłego: prosta - напишу, скажу (pol. napiszę, powiem), złożona syntetyczna - писатиму, писатимеш (transl. pysátymu, pysátymesz) i złożoną analityczna - буду писати, будеш писати (transl. budu pysaty, budesz pysaty, pol. napiszę, będe pisat, będe pisać).

\section{CZAS PRZESZLY}

Jak zaznaczono powyżej, w języku prasłowiańskim istniał skomplikowany system form czasowych, zwłaszcza czasu przeszłego. Czasowniki wyrażające czynność przeszła miały cztery formy - dwie proste i dwie złożone. Pierwsza $z$ form prostych - aoryst - stosowano w wypowiedziach do oznaczenia czynności krótkotrwałej, jednokrotnej, dokonanej w przeszłości, niepowiazanej z momentem mówienia. Wypowiedzi z użyciem tej formy odpowiadały na pytanie: co sie stało? Druga prosta forma czasu przeszłego było imperfektum, które, w odróżnieniu od aorystu, wyrażało akcję długotrwałą, niedokonana, powtarzająca się w przeszłości. Formy tego czasu odpowiadały na pytanie - co sie działo? Imperfektum, również $\mathrm{w}$ funkcji aorystu, było używane tylko w pisemnych relacjach zdarzeń przeszłych, to jest było relatywna formą czasowa [Бевзенко, Грищенко 1978, 288].

Imperfektum prasłowiańskie to forma innowacyjna, która powstała po rozpadzie języka praindoeuropejskiego [Мельничук 1966, 233]. Коnieczność jej powstania była spowodowana brakiem par aspektowych czasowników dokonanych i niedokonanych [Мейe 1951, 220]. Imperfektum wyrażało czynność przeszłą niedokonaną. Właśnie taka forma imperfektum utworzona od tematu bezokolicznika czasownika aspektu niedokonanego jest uważana za naturalny [Маслов 1984, 111] typ tej kategorii temporalnej. Był on używany często do opisu różnych okoliczności towarzyszących akcji wyrażonej aorystem: obyczajów, sytuacji, które tworzyły odpowiednie tło podkreślające dynamikę wypowiedzi.

W przeciwieństwie do imperfektum aoryst tworzono przeważnie od czasowników oznaczających czynności dokonane i taka była jego zasadnicza funkcja - opis akcji skończonej w przeszłości. Co prawda, niekiedy $\mathrm{w}$ tekstach staro-cerkiewno-słowiańskich spotykamy także 
aorysty utworzone od czasowników nazywających czynności niezakończone.

Konkludując, zasadniczą funkcja aorystu prasłowiańskiego było wyrażenie akcji dokonanej (skończonej) w przeszłości, a funkcją imperfektum - czynności niedokonanej (niezakończonej).

Dwie pozostałe formy - forma czasu przeszłego i forma czasu zaprzeszłego języka prasłowiańskiego - były złożone. Czas przeszły złożony niektórzy badacze określaja jako perfektum (łac. perfect), a czas zaprzeszły jako plusquamperfectum (łac.). Dowodem na pochodzenie tych form $z$ języka praindoeuropejskiego jest obecność podobnych form (imperfektum, perfektum oraz plusquamperfectum) we współczesnych językach europejskich, na przykład w języku niemieckim.

Czas przeszły złożony miał pierwotnie znaczenie perfektum, które wyrażało czynność dokonana w przeszłości. $Z$ czasem jednak, jak zaznacza Zenon Klemensiewicz, „ten odcień znaczeniowy osłabł, a forma czasu przeszłego złożonego oznacza po prostu jakąś akcję w przeszłości” [Klemensiewicz, Lehr-Spławiński, Urbańczyk 1981, 370], lecz aktualną w momencie mówienia, dlatego nazywa się go jeszcze czasem teraźniejszo-przeszłym. Znaczenie czasowe wyrażane przez perfektum było absolutne. W odróżnieniu od aorystu i imperfektum form czasu przeszłego złożonego używano zwykle w dialogach, podczas rozmów.

Plusquamperfectum wyrażało czynność dawno miniona albo czynność, która poprzedza inną minioną akcję. Czasu zaprzeszłego używano zarówno w relacjach pisemnych, jak i komunikacji ustnej.

Dawne języki słowiańskie, zakorzenione w języku prasłowiańskim, odziedziczyły po nim wszystkie wymienione wyżej formy czasu przeszłego, które następnie podlegały różnym procesom. W niektórych systemach językowych się zachowały, w innych uległy modyfikacji, w jeszcze innych zaginęly.

Jeszcze $\mathrm{w}$ polszczyźnie przedhistorycznej zaszły zmiany $\mathrm{w}$ formach osobowych imperfektum. Polegały one na kontrakcji samogłosek $a a>a$, ěa $>e$, wskutek czego formy prasłowiańskie typu *dělaachь, *viděachь zostały zmienione na dzialach, widziech. Oprócz tego zmiany zaszły też w 2. os. 1m., w której formy prasłowiańskie typu *dělaašete, *viděašete w staropolszczyźnie obok prawidłowych, regularnych form działaszecie, widzieszecie miały też działaście, widzieście, powstałe pod wpływem form aorystu. Analogiczne zmiany w formach imperfektum zaszły również w języku staroukraińskim.

Ze wszystkich prasłowiańskich form aorystu w języku staropolskim zachował się tylko aoryst sygmatyczny $z$ bezokolicznikowo-aorystycznym tematem o wygłosie samogłoskowym typu *pisach, *chvalich.

Jeśli tematy bezokolicznika były równe rdzeniowi zakończonemu na spółgłoskę, to rozszerzały się o samogłoskę $e$ i właśnie do tego tematu dodawano końcówki osobowe (kładzie-ch-ヶ > kładzie-ch, kładzie-ch-omヶ $>$ kładzie-chom, kładzie-ś-cie > kładzie-ście, kładzie-ch-a > kładzie-chą. 
Jest to tak zwany aoryst „nowy”, który w dawnym języku ukraińskim rozszerzał rdzeń bezokolicznika o samogłoske o (idochr, idochomъ, idoste, idoszę). Warto zaznaczyć, że w blisko spokrewnionych językach, takich jak staroczeski i starosłowacki, samogłoski były różne - w języku staroczeskim $-e, \mathrm{w}$ języku starosłowackim $-o$.

Pewne zmiany zaszły również w końcówkach osobowych aorystu na podłożu polskim. Jak wyżej wspomniano, prasłowiańska końcówka 3. os. lm. -šę zmieniła się, jak można przypuszczać, pod wpływem imperfektum na -chą. Paradygmat aorystu w staropolszczyźnie przedstawiał się zatem następująco: chwalich, chwali (2. i 3. os. 1p.), chwalichom, chwaliście, chwalicha; kładziech, kładzie (2. i 3. os. 1p.), kładziechom, kładzieście, kładziecha.

Warto dodać, iż ani w aoryście, ani w imperfektum staropolszczyzna nie zachowała form liczby podwójnej, które występowały w języku prasłowiańskim [Klemensiewicz, Lehr-Spławiński, Urbańczyk 1981, 368].

$\mathrm{W}$ ten sposób formy aorystu i imperfektum w języku staropolskim wzajemnie na siebie wpływały. Kontrakcja samogłosek, wymiana końcówek 3. os. $1 \mathrm{~m}$. w aoryście i 2 . os. $1 \mathrm{~m}$. w imperfektum spowodowały, że paradygmaty aorystu i imperfektum stały się identyczne ( $z$ wyjątkiem 2. i 3. os. lp.) i ustalenie, której formy użyto w danym tekście - aorystu czy imperfektum - stało się niemożliwe. Zatem obie te pierwotnie różne formy, jak zgodnie twierdzą historycy języka polskiego, „spłynęły do wspólnej formy" [Klemensiewicz, Lehr-Spławiński, Urbańczyk 1981, 368]. Ujednolicenie paradygmatów stało się jedną z przyczyn zaniku aorystu i imperfektum.

Wszystkie typy aorystu i imperfektum powszechnie występowały $\mathrm{w}$ tekstach języka staro-cerkiewno-słowiańskiego, jednak w wielu językach słowiańskich zaginęły. Zachowały się one tylko we współczesnym języku bułgarskim, serbskim, chorwackim, macedońskim, górno- i dolnołużyckim. Jednak w językach wschodniosłowiańskich, polskim, czeskim, słowackim, słoweńskim formacje te zostały wyparte przez formę czasu przeszłego złożonego, który łatwiej było uzgodnić $z$ poczuciem różnicy między dokonanością a niedokonanością, stopniowo stającej się odrębną kategorią w językach słowiańskich. W związku $z$ tym istnienie dwu form dla zróżnicowania czynności dokonanej i niedokonanej w czasie przeszłym stało się zbyteczne, a nawet uciążliwe.

W dawnym języku ukraińskim formy aorystu i imperfektum w żywej mowie, jak stwierdza większość badaczy, zanikaja już w XII-XIII wieku (formy aorystu i imperfektum nie występowały w tzw. żywej mowie i były wykorzystywane tylko przez wykształconych, piśmiennych użytkowników języka), co powoduje upowszechnienie perfektum i jednocześnie zmiany jego form oraz semantyki. Można tak przypuszczać na podstawie braku form imperfektum $\mathrm{w}$ drukowanych zabytkach staroukraińskich z XII-XIV wieku. Bardzo rzadko występuja formy aorystu, te jednak sa powszechnie używane w słowiańskich tekstach pisanych. Analizu- 
jąc drukowane zabytki czasów Rusi Kijowskiej, S. Obnorski oszacował, że w Słowie o pułku Igora aorystu użyto aż 155 razy, a imperfektum tylko 40. Tak duża liczba użyć form aorystu i imperfektum, jak zaznacza S. Obnorski, świadczy o przynależności obu tych form do powszechnych norm języka literackiego w owym czasie. Ponadto, jak uważa uczony, dużą frekwencję aorystu można wyjaśnić narracyjnym charakterem tekstu [Обнорский 1960, 59].

Można zatem domniemywać, że to przede wszystkim charakter zabytku, jego rodzaj, a także wykształcenie autora, determinowały występowanie tej formy w tekstach.

Często występujące formy aorystu charakteryzuja teksty Pouczenia Wołodymyra Monomacha i Latopis Halicko-Wołyński, które również maja charakter narracyjny. Natomiast w Prawdzie Ruskiej użyć imperfektum nie odnotowano w ogóle i zarejestrowano tylko pięć przykładów użycia aorystu, które, jak ustalił S. Obnorski, sa późniejszymi wstawkami do tekstu. Uważa on, że w języku Rusi Kijowskiej w ogóle nie było form aorystu. Jego zdaniem zanikły one w wyniku zbieżności funkcji z perfektum [Обнорский 1960, 133], lecz później aoryst stał się w języku tradycyjna forma książkową wykorzystywana przeważnie w tekstach konfesyjnych.

Język staroukraiński przejął również formy aorystu i imperfektum, lecz sa one traktowane jako formy archaiczne wykorzystywane w celu stylizacji na język staro-cerkiewno-słowiański [Безпалько, Бойчук 1962, 342].

W zabytkach języka staroukraińskiego w celach archaizacji form aorystu używano jeszcze dość długo, nawet do wieku XVII. Przykładowo, używanie obu prostych form czasu przeszłego zauważa się w utworach Petra Mohyły, w tym nawet w tekstach niezwiązanych $z$ religia, lecz stylizowanych na starożytne, o czym można sądzić na podstawie następujacego cyatu:

Въ град屯 БЪАоцерковскімъ Яну Пігловскомү роднся Аъщі. По оБычаю ж БаБа, въспрнмшн

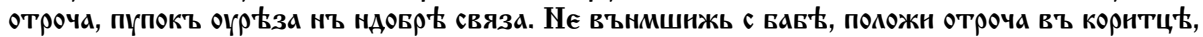
ОБЪ ношть же кровь нзъ отрочат тчаше пүпкомъ, кровію же іспиъвъ оүмнраше (trans. Whradi Biłocerkowskim Janu Pihłowskomu rodisia dszczi. Po obyczaju że baba, wosprijemszi otrocza, pupokъ uriza, nъ niedobpi swiaza. Nie wniemsziż sie babi, połozi otrocza wъ korytci, obъ nosztb że krowb izъ otroczate teczasze pupkomъ, krowiju że isplъwъ, umirasze) [Житецкий 1889, 38].

Fragment ten w języku polskim brzmi następująco:

W mieście Białocerkowskim u Jana Pigłowskiego urodziła się córka. Zgodnie ze zwyczajem więc baba (położniczka), odebrawszy dziecko, obcięła pępowinę, lecz niedobrze ją zawiązała. Jednak tego nie spostrzegła, położyła dziecko do koryta. Krew całą noc ciekła z pępka i do rana dziecko zmarło (tłum. własne).

W przytoczonym fragmencie występuja następujace formy aorystu: rodi (sia) 'urodziła się', uriza 'obcięła', swiaza 'zawiązała', położi 'poło- 
żyła'. Są tutaj również dwie formy imperfektum: teczasze 'ciekła' i umirasze 'umierało'. ${ }^{4}$

W pisanych zabytkach staroukraińskich z XIV-XV wieku aoryst prawie nie występuje. Poświadczone sa dwie formy aorystu (размыслихъ - razmyslich, поклонихомъ ся - pokłonichom sia ('pomyślałem', 'ukłoniliśmy się) w zabytku z 1446 r.; nie ma żadnej formy w Apostole Krechowskim, jednak w utworach A. Radywołowskiego, w latopisie Hrabianki występuje wiele ich użyć [Житецкий 1889, 341]. Dotyczy to również imperfektum, którego używano jeszcze rzadziej i które zaginęło jeszcze wcześniej.

Analogicznie aoryst i imperfektum zaginęły w staropolszczyźnie. W najstarszych zabytkach piśmiennictwa doby staropolskiej formy aorystu i imperfektum występuja rzadko, sa to formy archaiczne. Na przykład, w Kazaniach świętokrzyskich (najstarszy zabytek języka polskiego z XIV wieku) odnotowano tylko 8 form aorystu i imperfektum, w Psatterzu floriańskim - 13, w Psałterzu puławskim - 2, w Zapisce sadowej [1401] - 2, w Biblii Szaroszpatackiej - tylko jedna. W innych zabytkach występują formy aorystu, ale tylko dla czasownika być [Klemensiewicz, Lehr-Spławiński, Urbańczyk 1981, 368].

Badacze historii języka polskiego znaleźli w najdawniejszych zabytkach polskich tylko 26 form aorystu i imperfektum [Klemensiewicz, Lehr-Spławiński, Urbańczyk 1981, 368] i tylko trzy z tej liczby (mołwich, pospieszycha, poczęcha) z pewnością można zaliczyć do aorystu, a siedem form (siedziesze, mołwiasze, mołwiach, biesze, wychadzasze, błogosłowiacha, biecha) do form imperfektum. $Z$ wyjatkiem form poczęcha, pospieszycha, błogosławiacha, biecha wszystkie te formy można uznać zarówno za aoryst, jak i za imperfektum [Klemensiewicz 1961, 118].

Rozpoznanie aorystu było utrudnione także dlatego, że jego formy w 2. i 3. os. 1p. były identyczne $z$ formami 3. os. lp. czasu teraźniejszego, które już w dobie staropolskiej straciły końcówkę prasłowiańską to $<{ }^{*} t \bar{t}$. W zwiazku $z$ tym niekiedy nawet za pomoca kontekstu trudno rozstrzygnąć wątpliwość, ustalić formę czasową: czy są to szczątki aorystu, czy formy czasu teraźniejszego, np.: Gdyż wynidzie Tobiasz chcac swe nogi umyć $w$ rzece, wysunawszy sie jedna wielika ryba, chcac ji połknać. Jejże sie Tobiasz użask, pocznie wołać wielikim głosem... [za: Klemensiewicz, Lehr-Spławiński, Urbańczyk 1981, 369].

$\mathrm{W}$ zacytowanym fragmencie czasowniki wynidzie, pocznie można traktować jako formy aorystu (wyszedt, zaczą), lecz jednocześnie można uznać je za formy czasu teraźniejszego (dokonanego) stosowane w znaczeniu czasu przeszłego.

Obserwujemy zatem zanik prostych form czasu przeszłego również w języku staropolskim. Jednak zarówno we współczesnym języku

4 Jak widać $z$ kontekstu, forma imperfektum umirasze (umierało) tutaj została użyta w znaczeniu niewłaściwym. Właściwa w tym kontekście jest forma aorystu umrie, o ile chodzi o czynność dokonaną. 
polskim, jak i ukraińskim zachowały się szczątki aorystycznych form czasownika być. W języku ukraińskim sa to: partykuła by $(b) \mathrm{w}$ trybie przypuszczającym, a także elementy by $(b)$ w spójnikach jakby, aby, szczob, które etymologicznie reprezentuja formę 2. i 3. os. 1p. aorystu czasownika być. Ponadto w języku rosyjskim, jak uważa P. Kuzniecow, szczątkiem aorystu jest wykrzyknik uy! (czu!), który reprezentuje formę aorystu 2. os. lp. czasownika czuty 'сzuć' [Кузнецов 1953, 239].

W gwarze huculskiej i bukowińskiej języka ukraińskiego w trybie przypuszczającym zachowała się również forma 1. os. lp. aorystu czasownika być - bych, np.:

\footnotetext{
Довбуш: - Єк бих ділив свій маєток, то межи усіма по рівні пайці. Нате вам по вівці, єк богатому, так бідному... я бих давав усім рівно; transl. Dowbusz: Jek bych diływ swij majetok, to meży usima po riwni pajci. Nate wam po wiwci, jek bohatomu, tak bidnomu... ja bych dawaw usim riwno [H. Chotkewycz]; tlum. własne - Dowbusz: Jeśli bym dzielił swój majątek, to między wszystkimi po równej części. Bierzcie sobie po owcy, tak bogaty, jak biedny... dawałbym wszystkim na równi; А чомy бих мала мовчати, га? Я не буду мовчати!!, transl. A czomu bych mała mowczaty, ha? Ja ne budu mowczaty! [J. Fed'kowycz]; ttum. własne Dlaczego miałabym milczeć? Nie będę milczeć!
}

W języku polskim szczątki aorystu czasownika *byti również zachowały się w trybie przypuszczającym, lecz podobnie jak w języku ukraińskim tylko w 2. i 3. os. lp. - by. Formę 1. os. lp. bych można było spotkać jeszcze nawet w pierwszej połowie XVII w., ale bardzo rzadko. Została ona bowiem wyparta przez formę bym. Prasłowiańska forma bych jednak zachowała się w niektórych gwarach języka polskiego i do dzisiaj, a we współczesnym języku czeskim jest ona forma normatywna, standardowa [Havranek, Jedlička 1960, 251]. Stopniowo do końca pierwszej połowy XVI w. zanikały również formy 1 . i 3. os. $1 \mathrm{~m}$. bychom, bycha. We współczesnym języku polskim forma aorystu 2. i 3. os. 1p. by w trybie przypuszczającym połaczyła się ze szczątkami form osobowych czasownika być czasu teraźniejszego -m, -ś, -śmy, -ście (o tym będzie dalej), wskutek czego utworzyły się formy by-m, by-ś, by-śmy, by-ście.

$\mathrm{W}$ ten sposób imperfektum i aoryst stopniowo zanikły nie tylko w języku mówionym, potocznym, lecz także w języku pisanym. Zostały one zastapione, jak wspomniano powyżej, forma analityczna. Można wyodrębnić kilka przyczyn, które spowodowały to zjawisko. Główna $z$ nich to ta, że w czasowniku słowiańskim rozwija się gramatyczna kategoria aspektu. Wyznacznikiem tej kategorii stały się przedrostki czasownikowe, natomiast system końcówek aorystu i imperfektum utracił swoją funkcjonalność, co w dużej mierze było spowodowane poprzednią fuzją końcówek osobowych tych dwu form czasowych.

Druga ważna przyczyna zaniku prostych form czasów przeszłych było coraz częstsze i szersze używanie formy złożonej do oznaczenia czynności w przeszłości, przy czym zarówno skończonej, jak i niezakończonej. W rezultacie perfektum stało się uniwersalną formą, którą można było tworzyć i od czasowników aspektu dokonanego, i od czasowników aspektu niedokonanego [Мазон 1958, 49]. 
Po trzecie, powstały homonimiczne dla aorystu i imperfektum formy 2. i 3. os. lp. W konsekwencji forma gramatyczna w izolacji nie wskazywała na osobę, można ją było ustalić tylko w kontekście (i to nie zawsze). Formy perfektum natomiast za pomoca czasownika posiłkowego *byti wyraźnie wskazywały kategorię osoby, dlatego stały się formą bardziej racjonalną.

Jako ostatni $z$ powodów zaniku prostych form czasów przeszłych należy wymienić połączenie, a następnie homonimiczność form aorystu i imperfektum, o czym już wspomniano wyżej. Wskutek kontrakcji zintegrowały się i w języku staropolskim, i w języku staroukraińskim formy

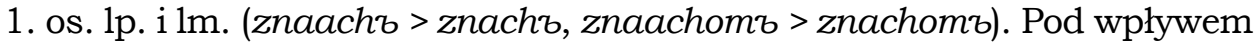
aorystu w obu językach zmieniła się, upodobniając się do aorystu, forma 2. os. lm. imperfektum (-szetie > -stie, w języku polskim - -szecie > -ście). Pod wpływem imperfektum końcówka 3. os. $\mathrm{lm}$. aorystu -szę zmieniła się w języku polskim na -cha, zaszły sporadyczne zmieszania form 3. os. $1 \mathrm{~m}$. $z$ formami 2. i 3. os. lp. aorystu w języku staroukraińskim (powidasze, stojasze zamiast powidasza, stojasza). Wszystkie te przyczyny przyspieszyły rozpad paradygmatu aorystu i imperfektum, uwarunkowały ich zanik.

Jednak i perfektum $\mathrm{w}$ takiej postaci, w której zostało przejęte $z$ języka prasłowiańskiego, przetrwało niedługo. W językach słowiańskich, które dążyły do zwięzłości, ekonomii formy wyrazu, w tym w języku staropolskim i staroukraińskim, perfektum okazało się konstrukcją zbyt rozbudowana. W związku $z$ tym $w$ obu językach już $\mathrm{w}$ najdawniejszych zabytkach spotyka się zniekształcone, skrócone formy czasownika posiłkowego *byti w 1 . i 2. os. obu liczb oraz pełny ich zanik w 3. os. $1 \mathrm{p}$. i $1 \mathrm{~m}$. Przyczynił się do tego fakt, że formy słowa posiłkowego były używane przeważnie w postpozycji i miały charakter enklityczny. Ponadto w języku staroukraińskim i pozostałych językach wschodniosłowiańskich już w XIV-XV w. bardzo często pomijało się słowo posiłkowe w 1. i 2. os. obu liczb, co stało się możliwe wskutek aktywnego używania w zdaniu $\mathrm{w}$ roli podmiotu zaimków osobowych ja, ty, my, wy. W celu uniknięcia redundancji wykładników kategorii osoby słowo posiłkowe *byti w formach czasu teraźniejszego stopniowo zanika.

W języku staropolskim formy prasłowiańskie czasownika *byti (*jesti) *jesmb, *jesi, *jestı, *jesmъ, *jeste, *sattı zmienily się na jeśm, jeś, jest, jeśmy, jeście, sa. Jednak już w wieku XIV traca one wyrazistość znaczeniową i przekształcają się w końcówki, swoiste przyrostki, które moga łączyć się zarówno $z$ imiesłowem na $-\ell$, jak i $z$ każdym innym słowem w zdaniu, co właśnie świadczy o uprzedniej ich samodzielności.

$\mathrm{W}$ ten sposób forma jeśm ulega redukcji do -śm, a potem do - $m$ [Lehr-Spławiński 1978, 135], które zostało utrwalone w Spowiedzi powszechnej (poczatek XV wieku): jakośm zgrzeszyt, com się dopuścit. W 2. os. lp. forma jeś przeszła w ś (eś): ${ }^{5}$ iżeś jadł, słyszałaś itp. Forma 3. os. 1p. jest $\mathrm{w}$ języku staropolskim miała formę równoległa - jeść (porównajmy rosyj-

5 Samogłoska $e$ w rodzaju męskim odgrywa rolę wstawki eufonicznej. 
skie ecmъ), często używana była też forma je (porównajmy ukraińskie $\epsilon$, czeskie i in. je). W 1. os. $1 \mathrm{~m}$. forma jeśmy $y^{6}$ przeobraziła się $\mathrm{w}$-śmy; tutaj pod wpływem innych form osobowych [Bakk 1978, 303] odbyło się zmiękczenie spółgłoski s: robili(ły)śmy, jechali(ły)śmy, pisali(ły)śmy. Pierwotna forma polska 2. os. lm. jeście skraca się do -ście: czekaliście, robiliście, chlebaście nie jedli i in.

W języku staroukraińskim redukcja złożonych form perfektum odbywała się powoli i dokładne ustalenie czasu zaniku form czasownika posiłkowego jest trudne; spotykano je jeszcze nawet w wieku XVI-XVII, na przykład: Создал єси сіє или из оутробы матєрє с собою на жизнь єси то извлек?, transl. Sozdal jesi sije ili iz utroby mat'er'e s soboju na żizń jesi to izwliek? [Хрестоматія... 1967, 124]; tłum. własne - Stworzyłeś to czy $z$ łona matki ze soba na życie to wyciagnąeś?

Można również spotkać w języku staroukraińskim i staropolskim kontaminację form:

Климко: Зблудилесь! А хочеш міні віріти? Здаст мі ся щом міл відити тепер чоловіка того, що міл горщков вельмі много. Тась ти його не шукал? Стецько: Ніт, бо ся ти натрапілесь; transl. Kłymko: Zbłudyłeś! A choczesz mini wirity? Zdast mi sia, szczom mił widity teper czołowika toho, szczo mił horszczkow welmi mnoho; Taś ty joho ne szukał? Stećko: - Nit bo sia ty natrapiłeś [Хрестоматія... 1967, 213]; ttum. własne - Kłymko: Zbłądziłeś! A chcesz mi wierzyć? Zdaje mi się, że miałem widzieć tego człowieka, który miał garnków bardzo dużo; Nie szukałeś go? Stećko: - Nie, ponieważ ty się trafiłeś.

Podobnie jak w języku polskim, w ukraińskich zabytkach piśmiennictwa znajdujemy szczątki czasownika byti - $-(-e m,-\epsilon M),-c(-c b,-e c b,-\epsilon c b)$, -смо (-змо), -cme '-m (-em, -jem), -s (-eś, jeś), -smo (-zmo), -ste', które również są ruchomymi końcówkami przyłączanymi albo do imiesłowu czynnego czasu przeszłego, albo do innego wyrazu w zdaniu: Чоловікам ошукал - признамся до того, transl. Czołowikam oszukat - pryznam sia do toho [Хрестоматія... 1967, 214], tłum. własne Człowieka oszukałem, przyznaje się do tego.

We współczesnym języku ukraińskim takie formy się nie zachowały - jedyna forma czasu przeszłego sa dawne imiesłowy czynne czasu przeszłego na - $t$, które pełnią funkcję wskaźnika czynności przeszłej (np. він писав, вона писала, воно писало, вони писали, win pysaw, wona pysała, wono pysało, wony pysały); osobę w tym wypadku wskazują zaimki osobowe я, ти, він (вона, воно), ми, ви, вони, transl. ja, ty, win (wona, wono), my, wy, wony. Jednak w gwarach zachodnich języka ukraińskiego takich reliktowych form perfektum używa się bardzo często, np. u Wasyla Stefanyka:

А шо-м уздрів, та й сказав-см; Сотку ніби-с узєв, а додому шо несеш?; Та й навчила, та й сте по селі перечули, та й сте з діда насміхалися; transl. A szo-m uzdriw, ta j skazaw-jem: Sotku niby-s uziew, a dodomu szo nesesz?; Ta j nawczyła, ta j ste po seli pereczuły, ta $\mathrm{j}$ ste $\mathrm{z}$ dida nasmichałysia; ttum. własne - Co zobaczyłem i powiedziałem: Setkę niby wziąłeś, a do domu co niesiesz?; I nauczyła,

${ }^{6}$ Prasłowiańska końcówka 1 . os. $1 \mathrm{~m}$. ช (jer) w języku polskim pod wpływem zaimka osobowego my została zastapiona przez $y$. 
i we wsi słyszaliście, i z dziada naśmiewaliście się. U Iwana Franki: - Що вам, Довбущуку, - уговорював Петрій, - чому налягаєте на мене, аби-м вертався, сли ніяк не можу?; transl. - Szczo wam, Dowbuszczuku, - uhoworiuwaw Petrij, - czomu nalahajete na mene, aby-m wertawsia, sły nijak ne możu?, thum. własne - Co wam, Doboszczuku - wypytywał Petrij, - Dlaczego nalegacie na mnie, żebym wracał, jeśli nijak nie mogę?

Interesującym zjawiskiem $\mathrm{w}$ gwarach zachodnich współczesnego języka ukraińskiego jest używanie szczątkowych form 2. os. obu liczb czasu teraźniejszego czasownika być jako łącznika w orzeczeniu złożonym imiennym. Można to zjawisko zaobserwować w dialogach: - Не чую, шо ти кажеш! - Глухий-с?; transl. - Ne czuju, szo ty każesz! - Hłuchyj-s?, tłum. własne Nie słyszę, co mówisz! Głuchy jesteś? Analogiczne wyrazy spotyka się także w utworach zachodnioukraińskich pisarzy. Przykłady podobnych użyć odnotowano u I. Franki: То чого ж хочете від мене сли-сте такі фудульні?; Троха-м нездоров, але то не шкодит; transl. To czoho ż choczete wid mene, sły-śte taki fudulni?, Trocha-m nezdorow, ałe to ne szkodyt, thum. własne Więc czego chcecie ode mnie, jeżeli jesteście tacy honorowi?, Trochę jestem niezdrów, ale to nie szkodzi. We współczesnym języku ukraińskim opuszcza się łacznik, zatem zdania miałyby taki wygląd: Ty_ hluchyj? Wy_taki fudulni? Ja_ nezdorow. Prawda, niekiedy w celu stylizacji te archaiczne formy można znaleźć w tekstach współczesnych pisarzy: $B u$ месники тепер за них, ви месники єсте; transl. Wy mesnyky teper za nych, wy mesnyky jeste [M. Bażan], tłum. własne Wy jesteście teraz za nich mścicielami, wy mściciele jesteście. Analizowane formy występuja także w modlitwie: Отче нам, іже єси на небесах; transl. Otcze nasz, iże jesy na nebesach, pol. Ojcze nasz, który jesteś $w$ niebie...

Plusquamperfectum (czas zaprzeszły), jak o tym wspomniano powyżej, było stosowane w językach słowiańskich tam, gdzie była konieczność wskazania na miniona czynność, która w bliższym lub w dalszym czasie poprzedzała inną czynność miniona wyrażoną innymi formami czasu przeszłego [Генсьорський 1957, 64]. Jeśli perfektum wyrażało czynność odnosząca się do momentu mówienia, to w czasie zaprzeszłym czasownik * byti wykluczał jakikolwiek związek rezultatu czynności z momentem mówienia [Русанівський 1959, 86].

Języki słowiańskie przejęły $z$ języka prasłowiańskiego plusquamperfectum w postaci klasycznej, która tworzono za pomoca imiesłowu czynnego czasu przeszłego na $-t$ i imperfektum czasownika *byti (chodzitr biach's, chodzit' biasze, chodzili biachom's, chodzili biaszetie, chodzii biacha). Jednak w niektórych językach ta forma $z$ czasem zanika, natomiast pojawia się nowa forma, która składała się $z$ perfektum czasownika *byti (bytr jesmъ, bytr jesi, bytъ jestb, byli jesmъ, byli jestie, byli sotb) i imiesłowu czynnego czasu przeszłego na - $t$. Zatem formy typu napisalt biasze zostały zastapione formami napisatı bytr jesmb.

W języku staroukraińskim używano obu tych form, pierwszej nawet częściej, na przykład: Въ то время ҺХалъ вше Аанниъ во Угры королевн 
н еще БО Бшеть не слышалъ прнХОАа поганыХЪ Татаръ на Кыевъ [ВолЫНско-Галицкая... 1871: 61]; transl. „W to wremja jichałъ biasze Daniłъ wo Ugry korolewi, i jeszcze bo biaszets nie słyszałъ prichoda pohanychъ tatarı na Kyjew`”, tłum. własne W ten czas był pojechał Danił na Wegry ku królowi $i$ wtedy jeszcze nie słyszał nic o najeździe tatarów na Kijów. Jednak w późniejszych zabytkach staroukraińskich przeważa forma nowsza (были есмы послали нашего посла [Безпалько, Бойчук 1962, 347], transl. byli jesmy posłali naszeho posła = byliśmy posłali naszego posła), w której z czasem opuszcza się ( $z$ tych również przyczyn, co i w perfektum) słowo posiłkowe *byti w czasie teraźniejszym. Zatem formy typu napisat๖ bytъ jesmı przeobrażaja się w formy napisałъ byłъ. Forma ta od wieku XVI staje się obowiąująca [Русанівський 1970, 260] i we współczesnym języku ukraińskim jest normatywna:

О щоб були мої осліпли очі, було б в душі ясніше і спокійніше [I. Franko]; transl. O szczob buły moji oslipły oczi, buło b w duszi jasnisze i spokijnisze; Знов узялися за лопати всі чорнороби, що вчора були зовсім покинули цей котлован [J. Basz]; transl. Znow uziałysia za łopaty wsi czornoroby, szczo wczora buły zowsim pokynuły cej kotłowan; thum. własne - O żeby były moje oczy oślepły, byłoby w duszy jaśniej i spokojniej; Znów wzięli łopaty do rąk wszyscy robotnicy, którzy wczoraj byli całkiem porzucili ten wykop.

W języku staropolskim używano nowszej formy plusquamperfectum. Zwłaszcza często występuje ona w Kazaniach gnieźnieńskich [XV w.], np.: Maria swego synka jest porodzić była miała [Lehr-Spławiński $1978,132]$. Trzeba jednak zauważyć, że w wielu wypadkach czas zaprzeszły znaczeniowo nie jest niezbędny, nie oznacza czynności zaprzeszłej. Niekiedy używa się tej formacji w języku doby późniejszej: Niebo a morze - te dwie rzeczy były świat zastapiły; wszystko był opanował cny naród słowiański [Klemensiewicz, Lehr-Spławiński, Urbańczyk 1981, 373]. We współczesnym języku polskim formacji czasu zaprzeszłego używa się bardzo rzadko wyłącznie w celach stylizacyjnych.

Jak wskazuja badania historyczno-porównawcze, w ewolucji systemu form czasów języka polskiego i ukraińskiego występuje dużo wspólnych cech i tendencji, co można wyjaśnić wspólnym pochodzeniem języków wschodnio- i zachodniosłowiańskich. Jednocześnie dla każdego $z$ obu języków, zarówno polskiego, jak i ukraińskiego, charakterystyczne sa własne specyficzne cechy rozwoju i stabilizacji gramatycznej kategorii czasu i sposobów jej wyrażania.

\section{Bibliografia}

P. Bak, 1978, Gramatyka jezyka polskiego, Warszawa.

K. Długosz-Kurczabowa, S. Dubisz, 2006, Gramatyka historyczna języka polskiego, Warszawa. 
B. Havranek, A. Jedlička, 1960, Česká mluvnice, Praha.

Z. Klemensiewicz, 1961, Historia języka polskiego, cz. I: Doba staropolska (od czasów najdawniejszych do początku XVI w.), Warszawa.

Z. Klemensiewicz, T. Lehr-Spławiński, S. Urbańczyk, 1981, Gramatyka historyczna języka polskiego, Warszawa.

T. Lehr-Spławiński, 1978, Język polski: pochodzenie, powstanie, rozwój, Warszawa.

S. Rospond, 1971, Gramatyka historyczna języka polskiego, Warszawa.

S. Urbańczyk (red.), 1978, Encyklopedia wiedzy o języku polskim, Wrocław.

С. Бевзенко, А. Грищенко і іп., 1978, Історія української мови. Морфологія, Київ.

О. Безпалько, М. Бойчук i in., 1962, Історична граматика украӥнської мови, Київ.

Х. Бирнбаум, 1987, Праславянский язык: Достижения и проблемы в его реконструкиии, Москва.

Н. Ван-Вейк, 1957, История древнецерковнославянского языка, Москва.

Вольнско-Галицкая льтопись, составленная съ концемъ ХІІІ в. (1205-1292), 1871, Львовъ.

А. Генсьорський, 1957, Значення форм минулого часу в Галицько-Волинському літопису, Київ.

П. Житецкий, 1889, Очеркъ литературной истории малорусского наръчія въ XVII въкъ, Киевъ.

П. Кузнецов, 1953, Историческая грамматика русского языка. Морфология, Москва.

А. Мазон, 1958, Вид в славянских языках (принцииьы и проблемы), Москва.

Ю. Маслов, 1984, Очерки по аспектологии, Ленинград.

А. Мейе, 1951, Общеславянский язык, Москва.

О. Мельничук (red.), 1966, Вступ до порівняльно-історичного вивчення слов'янських мов, Київ.

С. Обнорский, 1960, Избранные работы по русскому языку, Москва.

В. Русанівський, 1959, Значення $і$ взаємозв'язок граматичних категорій виду $i$ часу в украӥнській мові XVI-XVII ст., Київ.

В. Русанівський, 1970, Структура украӥнського дієслова, Київ.

Хрестоматія давньої української літератури (до кінця XVIII cm.), 1967, Київ.

\section{Spis stosowanych skrótów}

$\begin{array}{ll}\mathbf{l m} . & \text { liczba mnoga } \\ \mathbf{l p .} & \text { liczba pojedyncza } \\ \text { os. } & \text { osoba } \\ \text { pie. } & \text { język praindoeuropejski } \\ \text { pol. } & \text { język polski } \\ \text { przyp. red. } & \text { przypis redaktora } \\ \text { psł. } & \text { język prasłowiański } \\ \text { scs } & \text { język staro-cerkiewno-słowiański } \\ \text { stpol. } & \text { język staropolski } \\ \text { stukr. } & \text { język staroukraiński } \\ \text { tłum. wlasne } & \text { tłumaczenie własne } \\ \text { transl. } & \text { transliteracja } \\ \text { ukr. } & \text { język ukraiński }\end{array}$




\section{Gramatyczna kategoria czasu w języku polskim i ukraińskim w ujęciu diachronicznym}

\section{Streszczenie}

Artykuł przedstawia historię kształtowania się kategorii czasu w języku polskim i ukraińskim, to jest form czasu teraźniejszego, przyszłego i przeszłego na podstawie rekonstrukcji odpowiednich, analogicznych form języka prasłowiańskiego. Autor szczegółowo analizuje proces kształtowania się form czasowych w obu językach, ujawniając ich cechy wspólne i specyficzne. Materiał oparty jest na pracach wybitnych językoznawców europejskich (A. Meillet, N. van Wijk, Z. Klemensiewicz, T. Lehr-Spławiński, S. Urbańczyk, S. Dubisz, P. Żytec'kyj, W. Rusaniws'kyj, P. Kuzniecow i in.). Autor podaje pełny obraz systemu form czasowych i gramatycznej kategorii czasu w sposób komplementarny w dwóch pokrewnych językach.

Słowa klucze: kategoria czasu - formy czasowe - podstawa czasownika końcówki osobowe - liczba pojedyncza - liczba mnoga - czas teraźniejszy - czas przeszły - czas przyszły - język prasłowiański.

\section{Grammatical category of time in Polish and Ukrainian from a diachronic perspective}

\section{Summary}

The paper presents the history of shaping the category of time in Polish and Ukrainian, that is forms of the present, future and past tenses, based on a reconstruction of appropriate, analogous forms of the Proto-Slavic language. The author analyses the process of shaping tense forms in both languages in detail, revealing their common and specific features. The material is based on works by renowned European linguists (A. Meillet, N. van Wijk, Z. Klemensiewicz, T. Lehr-Spławiński, S. Urbańczyk, S. Dubisz, P. Zhyteckyi, W. Rusanivskyi, P. Kuzniecow, and others), a complete picture of the system of tense forms and the grammatical category of time in a complementary manner in two related languages.

Keywords: category of time - tense forms - verb root - personal endings singular - plural - Proto-Slavic language.

Adj. Monika Czarnecka 